\title{
PLAGIARISME DI KALANGAN MAHASISWA DALAM MEMBUAT TUGAS-TUGAS PERKULIAHAN PADA FAKULTAS TARBIYAH IAIN IMAM BONJOL PADANG
}

\author{
Muhammad Zalnur \\ Dosen Fakultas Tarbiyah IAIN Imam Bonjol Padang \\ e-mail:mad_zalnur@gmail.co.id
}

\begin{abstract}
The purpose of the study is to describe the types of plagiarism done by the students in finishing their lesson tasks. There are three factors that made students did the plagiarism, namely: (1) take other writings and acknowledge them as their own writing, (2) take ideas from part of others' writing and change to own language, and (3) take all parts of writings without changing the ideas and language. The causes of plagiarism are: (1) the development of technology and information and, (2) high lessen studi.
\end{abstract}

\begin{abstract}
Abstrak: Penelitian ini bertujuan untuk menggambarkan bentuk-bentuk perilaku plagiarisme yang dilakukan oleh mahasiswa dalam menyelesaikan tugas-tugas perkuliahan. Faktor-faktor penyebab timbulnya perilaku plagiarisme tersebut ada tiga bentuk, yaitu: (1) mengambil tulisan orang lain kemudian diakui sebagai karya sendiri, (2) mengambil ide atau batang tubuh pikiran orang lain untuk selanjutnya dirubah ke dalam bahasa sendiri dan (3) mengambil teks secara keseluruhan tanpa mengubah tulisan maupun menambah dengan analisis maupun komentar apapun. Pemicu terjadinya plagiarisme: (1) perkembangan teknologi informasi dan (2) tingginya intensitas tugas perkuliahan sedangkan alokasi waktu yang tersedia sangat terbatas.
\end{abstract}

Kata Kunci: plagiarisme, bentuk-bentuk perilaku plagiarisme, penyebab plagiarisme

\section{PENDAHULUAN}

Plagiarisme berasal dari bahasa latin plagiarus yang bermakna penculik (Saunders, 1993). Sedangkan di dalam kamus Law Dictionary (2003) plagiarisme didefinisikan sebagai berikut:

"Taking the writings or literary concepts (a plot, characters, words) of another and selling and/or publishing them as one's own product. Quotes which are brief or are acknowledged as quotes do not constitute plagiarism. The actual author can bring a lawsuit for appropriation of his/her work against the plagiarist and recover the profits. Normally plagiarism is not a crime, but it can be used as the basis of a fraud charge or copyright infringement if prior creation can be proved."
Sementara (Felicia Utorodewo 2007; Eri Wijaya 2008) telah menetapkan tujuh ciriciri tindakan plagiarisme yaitu:

1. karya kelompok sebagai kepunyaan atau hasil sendiri.

2. menyajikan tulisan yang sama dalam kesempatan yang berbeda tanpa mengakui tulisan orang lain sebagai tulisan sendiri.

3. mengakui gagasan orang lain sebagai pemikiran sendiri.

4. mengakui temuan orang lain sebagai kepunyaan sendiri.

5. mengakui menyebutkan asal-usulnya.

6. meringkas dan memparafrasekan (mengutip tak langsung) tanpa menyebutkan sumbernya.

7. meringkas dan memparafrasekan dengan menyebut sumbernya, tetapi rangkaian 
kalimat dan pilihan katanya masih terlalu sama dengan sumbernya.

Kramer et al (1995) dan Wray (2006) menyatakan bahwa palgiarisme terjadi ketika seorang penulis mengambil karya intelektual seperti gagasan, pendapat, temuan, simpulan, data, kalimat dan kata-kata orang lain sehingga pembaca menganggap bahwa karya intelektual itu merupakan karya penulis tersebut.

Dari defenisi serta pendapat di atas, maka dapat diambil sebuah kesimpulan bahwa tindakan plagiarisme merupakan salah satu "kejahatan intelektual" yang terjadi di dalam dunia akademik, kejahatan tersebut dapat tergambar dari perilaku pencurian, penipuan, penculikan dan pengakuan hasil penelitian maupun tulisan orang lain yang kemudian diakui sebagai karya sendiri.

\section{LATAR BELAKANG MASALAH}

Sebelumnya telah coba peneliti sentuh bahwa tindakan plagiarisme merupakan sebuah bentuk kejahatan di dalam dunia akademik. Di Indonesia kasus-kasus plagiarisme di dunia akademik bukan lagi isu yang baru. Menurut (Fasli Jalal 2010) bahwa tindakan plagiarisme (menjiplak) karya tulis ilmiah orang lain yang kemudian diakui sebagai karya sendiri sebenarnya sudah lama berlangsung di berbagai institusi perguruan tinggi di negeri ini. Beliau lebih lanjut menjelaskan bahwa sesungguhnya kasus plagiarisme tersebut tidak hanya dilakukan oleh para kaum civitas akademik seperti mahasiswa, dosen dan guru, akan tetapi juga dilakukan oleh pejabat publik di berbagai institusi pemerintah lainnya.

Pernyataan di atas menurut peneliti bukanlah tidak mempunyai dasar, perkara tersebut dapat dibuktikan dengan sebuah kasus berikut. Sebagai contoh peneliti akan mengungkapkan sebuah kasus plagiarisme yang menimpa $X$, seorang jaksa yang pernah dicalonkan sebagai pimpinan Komisi Pemberantasan Korupsi (KPK) beberapa tahun silam. Ia diduga melakukan tindakan plagiarisme dalam menyusun disertasi doktoralnya. Perkara tersebut terungkap ketika pada uji kelayakan dan kepatutan (fit and propertest) komisi III DPR mencurigai bahwa $\mathrm{X}$ telah melakukan tindakan plagiarisme lantaran menyelesaikan disertasinya hanya dalam waktu setahun. Wila Chandrawila anggota komisi III DPR waktu itu yang juga guru besar Fakultas Hukum Universitas Katholik Parahiyangan menyatakan, bercermin dari pengalamannya selama tiga puluh tahun membimbing disertasi para mahasiwa, mengungkapkan tidak pernah ada calon doktor yang mampu menyelesaikan disertasinya dalam tempo setahun.

Untuk mengatasi meluasnya permasalahan plagiarisme di dunia akademik maupun institusi pemerintahan di Indonesia tersebut, maka pemerintah sebenarnya telah membuat peraturan menyangkut sanksi bagi pelaku tindakan plagiarisme. Berdasarkan UU No. 20 tahun 2003 dinyatakan bahwa sanksi atas tindakan plagiarisme dalam persoalan karya tulis sebagai berikut. Lulusan PT yang karya ilmiahnya digunakan untuk memperoleh gelar akademik, profesi, atau vokasi, terbukti merupakan jiplakan, dicabut gelarnya (pasal 25 ayat 2). Lulusan yang tersebut pada pasal 25 ayat 2 dipidana dengan pidana penjara paling lama dua tahun, dan atau pidana denda paling banyak Rp. 200.000.000,- (dua ratus juta rupiah). (Yasasan Rumah Ilmu Indonesia. E-Journal 2010).

Maka menurut peneliti perlu diadakan kajian-kajian lanjutan tentang isu-isu sentral seputar perilaku plagiarisme seperti apakah bentuk-bentuk tindakan plagiarisme yang marak dilakukan oleh mahasiswa? Apakah faktor-faktor penyebab timbulnya perilaku plagiarisme tersebut?. Kajian-kajian dalam konteks dan isu yang berbeda juga perlu dilakukan sehingga dapat memperluas wawasan masyarakat luas kususnya kalangan akademik seperti mahasiswa, dosen dan guru tentang plagiarisme. Penelitian ini juga peneliti anggap begitu penting karena belum ada satupun kajian yang dilakukan oleh dosen 
maupun mahasiswa di IAIN Imam Bonjol Padang yang membicarakan plagiarisme.

\section{LANDASAN TEORI}

Para peneliti terdahulu seperti (Davis 1993; Fishbein 1993; Bowers 1994) menyatakan bahwa, tingginya angka tindakan plagiarisme yang terjadi di dunia akademik akhir-akhir ini merupakan sebuah bukti bahwa kaum intelektual seperti mahasiswa, dosen, guru, professional tidak lagi menjunjung tinggi asas-asas kejujuran dan etika dalam menghasilkan karya ilmiah sendiri. Jika diamati tindakan tersebut tentu sudah jauh dari nilai-nilai akademik karena telah merusak etika mencari kebenaran melalui ilmu. Temuan penelitian $\mathrm{di}$ atas diperkuat oleh pernyataan Menteri Pendidikan Nasional, Muhammad Nuh yang menyatakan bahwa, tingginya angka tindakan plagiarisme menunjukkan lemahnya pendidikan karakter, budaya, dan moral insan di dunia akademik (Rachmad 2010).

Tindakan plagiarisme tidak hanya melanda kawasan dunia akademik di Asia dan kususnya Indonesia, namun juga telah melanda akademik di kawasan Amerika dan Eropa. Di Eropa penelitian tentang tindakan plagiarisme juga telah banyak dikaji oleh kalangan pakar pendidikan maupun ahli penelitian. Misalnya, penelitian yang dilakukan oleh (Ashworth \& Bannister 1997) dengan judul Guilty in whose Eyes? University Students' Perceptions of Cheating and Plagiarism in Academic Work and Assessment. Studies in Higher Education di Inggris. Hasil penelitian menyimpulkan bahwa para mahasiswa di kampus tersebut kurang mempunyai informasi yang lengkap tentang apakah bentuk-bentuk tindakan yang dianggap sebagai plagiarisme. Perkara tersebut menyebabkan tindakan plagiarisme begitu bebas di kalangan mahasiswa ketika menyelesaikan tulisan-tulisan ilmiah pada perkuliahan.

Hasil penelitian di atas memperkuat temuan kajian sebelumnya yang juga pernah dijalankan di dunia pendidikan Amerika oleh (Sierles 1988; Jendrek 1992; Pavela 1993;
McCabe \& Bowers 1994) mereka menyimpulkan bahwa 30\% dari keseluruhan responden penelitian yang terdiri dari kalangan mahasiswa telah melakukan tindakan plagiarisme dalam membuat tugastugas perkuliahan mereka. Dan $70 \%$ lainnya pernah melakukan tindakan plagiarisme dalam bentuk yang bervariasi seperti, mengambil karya orang lain, mengambil ide pokok pikiran orang lain yang kemudian dijadikan hasil pemikiran sendiri dan mengambil tulisan orang tanpa mencantumkan sumbernya.

Hawley (1984) dengan judul Plagiarism in the University System. Improving College and University Teaching, kajian dilakukan kepada 425 orang mahasiswa. Beliau menyimpulkan $40 \%$ mahasiswa tersebut telah menggunakan iklan layanan penyediaan untuk memenuhi keperluan kuliah mereka. $12 \%$ mahasiswa pernah meminta bantuan mahasiswa lain untuk menyiapkan tugas mereka dan $21 \%$ mahasiswa mengaku telah mengantarkan tugas yang telah diselesaikan oleh oleh kawan mereka. Maka bila merujuk kepada hasil-hasil penelitian yang telah dilakukan oleh para peneliti terdahulu yang dimulai tahun 1984 hingga 1997 di atas secara keseluruhan dapat peneliti simpulkan bahwa, perilaku plagiarisme secara jelas setidaknya telah menjadi budaya dalam dunia akademik oleh mahasiswa. Hal tersebut dapat dilihat melalui tingginya angka statistik perilaku plagiarisme dikalangan mahasiswa dari beberapa penelitian terdahulu.

\section{TUJUAN PENELITIAN}

Secara umunya penelitian ini bertujuan untuk (i) mengetahui apakah bentuk-bentuk tindakan plagiarisme yang dilakukan oleh mahasiswa dalam menyelesaikan tugas-tugas perkuliahan, (ii) apakah faktor-faktor penyebab timbulnya perilaku plagiarisme di kalangan mahasiswa.

\section{A. Obyektif Penelitian}

1. Bagaimanakah bentuk-bentuk perilaku plagiarisme yang dilakukan mahasiswa dalam membuat tugastugas perkuliahan? 
2. Apakah faktor-faktor penyebab timbulnya perilaku plagiarisme di kalangan mahasiswa?

\section{B. Metodologi Penelitian}

1. Reka Bentuk Penelitian

Reka bentuk penelitian merupakan sebuah tatacara mengumpul dan mengolah data berdasarkan

perancangan kusus dan sistematik yang melibatkan seluruh variabelvariabel yang terlibat dalam sebuah penelitian (Chua 2006). Penelitian ini menggunakan metode kualitatif melalui pendekatan kajian kes (case study research design). Menurut (Yin 1994) metode ini tepat digunakan apabila seorang peneliti ingin membuat penelitian terhadap unit sosial yang kecil, seperti individu, satu keluarga, sebuah perkampungan, organisasi atau sebuah sekolah. Menurut beberapa pakar penelitian kualitatif seperti (Denzin \& Lincoln 1994; Bungin 2003) bahwa metode kualititatif dengan pendekatan kajian kes akan dapat membantu peneliti memahami permasalahan yang lebih kompleks dalam konteks yang lebih luas, walaupun unit yang terlibat dalam kajian kes agak kecil tetapi informasi yang diperolehi sangat mendalam. Adapun data penelitian dikumpulkan sepenuhnya melalui hasil wawancara mendalam dengan semua responden yang terlibat.

\section{Responden Penelitian}

Dalam penelitian ini, peneliti telah memilih sepuluh orang mahasiswa sebagai responden penelitian yang terdiri dari enam mahasiswa dan empat mahasiswi yang sedang belajar di Fakultas Tarbiyah IAIN-IB Padang. Adapun pemilihan responden penelitian tersebut dilakukan menggunakan teknik persampelan purpossive sampling, yaitu pemilihan responden penelitian tergantung kepada peneliti melihat responden yang ingin dipilih, adakah mereka dapat memberikan data sepenuhnya ataupun sebaliknya (Sugiyono
2005). Pendapat di atas diperkuat oleh Flick (1998) pemilihan responden untuk penelitian kualitatif adalah berdasarkan kepada keperluan data yang ingin dicari oleh peneliti. Sedangkan (Cresswel 2006) menyatakan bahwa pemilihan responden penelitian dalam sebuah kajian kualitatif tidak melihat kepada jumlah ataupun kuantitas sampel, namun yang terpenting adalah responden yang dipilih dapat memberikan data secara maksimal, sehingga data tersebut telah sampai kepada tingkat ketepuan data, (apabila responden telah memberikan data yang hampir sama).

3. Instrumen Penelitian

Alat penelitian ini adalah satu set daftar wawancara, yaitu panduan yang berisikan pertanyaanpertanyaan wawancara yang diajukan ketika peneliti melakukan wawancawa kepada seluruh mahasiswa yang terlibat dalam penelitian. Pertanyan- pertanyaan wawancara tersebut peneliti buat dalam bentuk pertanyaan terbuka, yaitu peserta wawancara bebas menyatakan pendapat mereka berdasarkan soal-soal yang diberikan tanpa dibatasi. Namun demikian, pewawancara (peneliti) tetap memandu perbincangan agar tidak meluas kepada perkaraperkara yang tidak berkaitan dengan penelitian yang sedang dijalankan (Yin 1994). Agar terstrukturnya wawancara tersebut peneliti telah memilih panduan 
$\begin{array}{lll}\text { wawancara } & \text { kualitatif } & \text { yang } \\ \text { dicadangkan oleh (Krueger 1994). }\end{array}$

Menurut beliau agar wawancara tersusun dengan rapi dan responden mudah memahami alur perbincangan maka peneliti penting menyusun protokol wawancara dalam beberapa bagian yaitu pertanyaan pembuka, pengenalan, transisi, kunci dan pertanyaan penutup.

4. Tatacara Analisis Data

Data yang telah peneliti dapatkan melalui wawancara mendalam (indepth interview) dengan semua responden dianalisis secara tematik. Menurut (Boyatzis 1998; Tuckeet 2005) analisis tematik adalah salah satu cara yang lebih fleksibel untuk mengidentifikasi, menganalisis dan melaporkan data yang dapat digunakan oleh seorang peneliti dalam sebuah penelitian kualitatif. Untuk mempermudah pembaca memahami hasil analisis tersebut peneliti juga menggunakan alat analisis penelitian kualitatif Nvivo 8 dengan menjadikan tema-tema tersebut menjadi sebuah sebuah model kurva. Sebelum seluruh data dimasukkan ke dalam alat analisis tersebut, seluruh hasil wawancara dengan semua responden dilakukan proses transkripsi berbentuk dialog atau verbatim. Kemudian data tersebut kembali dibaca secara berulangulang sampai peneliti memastikan tidak terjadi kesalahan-kesalahan transkripsi. Braun \& Clarke (2012) menyatakan adalah penting bagi seorang peneliti untuk menyimak kembali data-data wawancara yang telah ditranskripsikan dengan cermat dan teliti dengan membaca secara berulang-ulang, sebelum peneliti memulai proses memasukkan data untuk menentukan tema-tema penting yang berkaitan dengan data yang hendak dicari. Selanjutnya peneliti mencari tema-tema penting dari hasil wawancara tersebut untuk diinput ke dalam alat analisis.
Setelah selesai memasukkan data, proses dilanjutkan dengan analisis data dan diakhiri dengan laporan hasil kajian.

Perlu juga peneliti jelaskan bahwa Nvivo 8 merupakan sebuah alat analisis terkini dalam penelitian kualitatif yang bertujuan untuk memudahkan seorang peneliti mengorganisasikan, menganalisis dan melaporkan data-data penelitian kualitatif. Di Indonesia alat analisis ini belum banyak digunakan oleh para peneliti, karena secara umum masih banyak para peneliti yang bertahan dengan analisis tematik klasik atau secara manual.

\section{HASIL PENELITIAN}

Pada bagian ini peneliti akan melaporkan semua hasil penelitian yang disusun berdasarkan tujuan dan objektif kajian. Sebagaimana yang telah diterangkan sebelumnya bahwa penelitian ini mempunyai beberapa objektif, yaitu (i) mengetahui apakah bentuk-bentuk tindakan plagiarisme yang dilakukan oleh mahasiswa dalam meyelesaikan tugas-tugas perkuliahan, (ii) apakah faktor-faktor penyebab timbulnya perilaku plagiarisme dikalangan mahasiswa. Selanjutnya laporan hasil penelitian ini akan disusun berdasarkan tujuan dari penelitian sebagaimaan telah diterangkan di atas.

\section{a) Bentuk-bentuk Tindakan Plagia- risme yang dilakukan Mahasiswa dalam Menyelesaikan Tugas Perku- liahan}

Berdasarkan hasil penelitian yang telah dijalankan melalui wawancara mendalam (indepth interview) terhadap 10 orang mahasiswa pada Fakultas Tarbiyah di Institut Agama Islam Negeri Imam Bonjol (IAIN-IB) Padang, secara umumnya terdapat tiga tema penting yang berkaiatan dengan bentukbentuk tindakan plagiarisme yang sering dilakukan oleh mahasiswa dalam menyelesaikan tugas-tugas mata kuliah yang diberikan dosen dalam perkuliahan. Ketiga- 
tiga tema penting tersebut seperti terlihat pada tema model kurva di bawah.

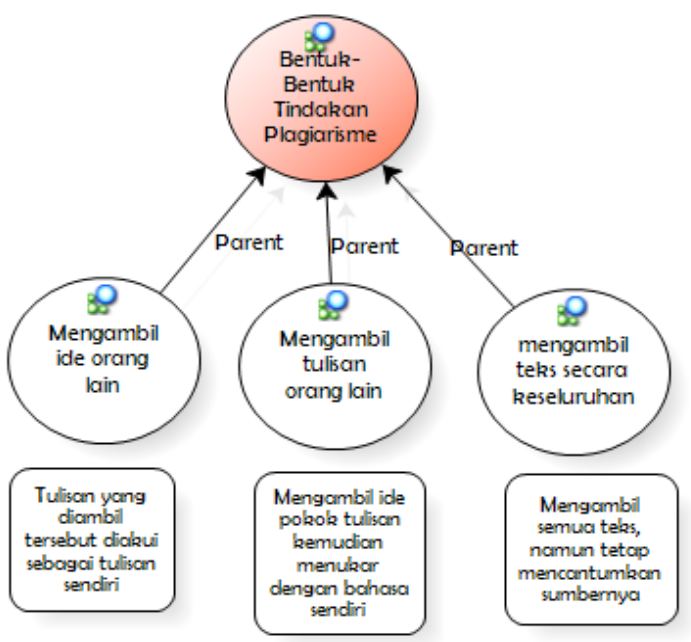

1.1 Bentuk-bentuk tindakan plagiarisme yang dilakukan mahasiswa dalam menyelesaikan tugas perkuliahan (Nvivo 8 Model)

Tiga tema di atas merupakan bentukbentuk perilaku yang paling sering atau yang sangat signifikan dilakukan oleh mahasiswa dalam menyelesaikan tugas-tugas perkuliahan. Ketiga-tiga tema ini akan dibahas di dalam dapatan kajian selanjutnya.

Untuk mempermudah memahami perbincangan yang dikemukakan oleh semua responden dalam wawancara, peneliti akan menggunakan kode-kode berikut untuk melaporkan hasil wawancara yang dijalankan. Kode-kode tersebut adalah seperti ditunjukkan dalam table 1.1 di bawah ini:

Table 1.1 Kode yang digunakan untuk melaporan hasil wawancara

\begin{tabular}{ll}
\hline Kode & Keterangan Kode \\
\hline M 1 & $\begin{array}{l}\text { Wawancara Mendalam dengan } \\
\text { responden 1 }\end{array}$
\end{tabular}

M 2 Wawancara Mendalam dengan responden 2

M 3 Wawancara Mendalam dengan responden 3

M 4 Wawancara Mendalam dengan responden 4

M 5 Wawancara Mendalam dengan responden 5

M 6 Wawancara Mendalam dengan responden 6
M 7 Wawancara Mendalam dengan responden 7

M 8 Wawancara Mendalam dengan responden 8

M.9 Wawancara Mendalam dengan

M10 responden 9 Wawancara Mendalam dengan responden 10

Melanjutkan pembahasan tema pertama yaitu (mengambil ide orang lain), menurut responden perilaku ini adalah tindakan para mahasiswa yang mengambil ide atau tulisan orang lain dari berbagai sumber yang ada, diantaranya melalui internet, makalah-makalah terdahulu dan buku-buku perkuliahan. Selanjutnya tulisan-tulisan yang mereka ambil tersebut diakui sebagai karya atau buah dari pemikiran mereka sendiri. Perbincangan responden terhadap tema ini sebagaimana dinyatakan oleh (M1, M4, M8) seperti tergambar dari beberapa hasil petikanpetikan wawancara berikut:

M.1 : budaya copy paste zaman sekarang memang biasa, internet memberikan kita informasi yang lumayan banyak, ambil saja di sana, praktis, walaupun membuat kita jadi pemalas, tanya mbah google saja.

M.4 : ,...fasilitas semua telah tersedia, tugas bisa dibuat dengan cepat, kalau tugas itu memang sudah umum ada di internet, copy dan print saja.

M.8 : ,...makalah kakak-kakak senior kan ada, secara umum topik-topik perkuliahan hampir sama, kalaupun tidak ditemukan makalah senior, di internet juga banyak bahan untuk menyelesaikan tugas kuliah.

Tema kedua yaitu (mengambil tulisan orang lain) menurut responden perilaku ini adalah tindakan para mahasiswa yang mengambil ide atau batang tubuh pemikiran orang lain kemudian mereka 
memparafrasakan tulisan orang lain tersebut dengan kalimat sendiri, walaupun ide atau batang tubuh tulisan tidak berubah. Berdasarkan dari data penelitian bentuk tindakan plagiarisme seperti ini secara umum dilakukan oleh hampir seluruh mahasiswa tidak terkecuali mereka yang terlibat dalam responden penelitian. Perbincangan responden terhadap tema ini sebagaimana dinyatakan oleh (M3, M6, M7) seperti tergambar dari beberapa hasil petikan-petikan wawancara berikut:

M.3 : "saya tidak terlalu paham cara mengutip dalam menulis karya ilmiah, saya cukup mengambil point-point penting kemudian saya ringkaskan keterangannya dan saya masukkan bahasa saya sebagai penambahnya.

M.6 : ,.. Saya memang tidak begitu mampu buat makalah sendiri, kalau harus jujur, waktunya lama, jadi saya ambil pikiran orang lain, kemudian saya ubah dengan gaya bahasa saya sendiri.

M.7 : makalah yang saya buat biasanya tidak persis sama bahasa dari bahasa buku, saya tulis dalam bahasa sendiri, tapi rujukannya tetap buku sumber yang diberikan dosen kemudian saya mencantumkan kutipannya.

Tema ketiga yaitu (mengambil teks secara keseluruhan) menurut responden perilaku ini adalah tindakan mahasiswa yang mengambil tulisan teks secara keseluruhan dari berbagai sumber diantaranya, internet, makalah terdahulu dan buku-buku sumber perkuliahan. Selanjutnya tulisan tersebut ditulis kembali tanpa ada tambahan dari mahasiswa tersebut baik berupa komentar, analisis, penerimaan, maupun penambahanpenambahan lainnya, sehingga tulisan tersebut terkesan seperti sebuah "kliping". Perbincangan responden terhadap tema ini sebagaimana dinyatakan oleh (M2, M3, M5) seperti tergambar dari beberapa hasil petikanpetikan wawancara berikut:

M.2 : Saya dan beberapa teman lainnya jika membuat tugas mengambil bahan dari internet, mencimplak begitu saja.

M.3 : Biasanya makalah yang kami buat seluruh isinya apa yang ada dalam buku...,

M.5 : Kami membuat tugas mengambil tulisan dari internet, buku atau makalah-makalah terdahulu, kita baut ajalah seperti yang kita ambil...,

Bentuk-bentuk tindakan plagiarisme mahasiswa seperti tergambar di atas diperkuat oleh temuan peneliti sendiri ketika mengajar mata kuliah Filsafat Umum. Makalah yang diserahkan mahasiswa kepada peneliti bersumber dari internet maupun makalahmakalah terdahulu, para mahasiswa hanya menambahkan daftar pustaka pada bagian belakang makalah, terkadang tugas makalah tersebut tidak di edit sehingga tugas tersebut terdapat banyak kesalahan-kesalahan, diantaranya kesalahan tanda baca, ejaan, bahkan gaya tulisan juga terkadang tidak berubah, masih seperti ketika mereka mengambil di internet.

Dari data di atas dapat disimpulkan bahwa, telah terjadi tiga bentuk tindakan plagiarisme yang dilakukan mahasiswa dalam menyelesaikan tugas-tugas perkuliahan yang diberikan oleh dosen. Ketiga-tiga bentuk plagiarisme tersebut adalah (i) mengambil tulisan orang lain yang diakui sebagai karya sendiri, (ii) mengambil idea tau batang tubuh pikiran orang lain untuk selanjutnya dirubah ke dalam bahasa sendiri dan (iii) mengambil teks secara keseluruhan tanpa mengubah tulisan maupun menambah dengan analisis maupun komentar apapun.

\section{b) Faktor-faktor Penyebab Timbul- nya Perilaku Plagiarisme di Kalangan Mahasiswa}

Berdasarkan hasil penelitian yang telah dijalankan melalui wawancara mendalam (indepth interview) terhadap 10 orang mahasiswa pada Fakultas Tarbiyah di Institut Agama Islam Negeri Imam Bonjol (IAIN-IB) Padang, secara umumnya terdapat dua tema 
penting berkaiatan faktor-faktor penyebab timbulnya perilaku plagiarisme di kalangan mahasiswa dalam menyelesaikan tugas-tugas mata kuliah yang diberikan dosen dalam perkuliahan. Kedua-dua tema penting tersebut seperti terlihat pada tema model kurva di bawah.

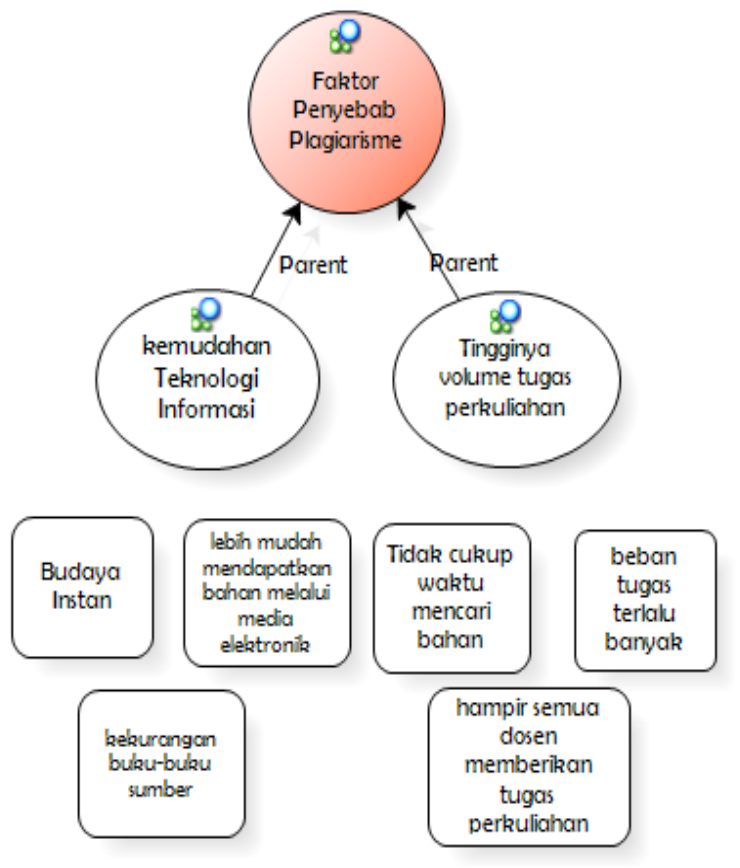

1.2 Faktor-faktor penyebab timbulnya perilaku plagiarisme dikalangan mahasiswa (Nvivo 8 Model).

Dua tema di atas merupakan faktor-faktor yang menyebabkan timbulnya perilaku plagiarisme di kalangan mahasiswa dalam menyelesaikan tugas-tugas perkuliahan. Kedua tema ini akan dibahas di dalam dapatan kajian selanjutnya.

Tema pertama yaitu (perkembangan teknologi) manurut responden perkembangan teknologi yang dimaksud adalah, kemajuan teknologi informasi yang terus berkembang sampai detik ini. Dengan adanya perkembnagan teknologi tersebut menyebabkan mahasiswa dengan mudah mendapatkan informasi-informasi yang dikehendaki, kemudahan tersebut dapat melalui media elektronik, cetak, majalah maupun surat kabar harian. Namun berdasarkan hasil penelitian ini, semua responden lebih memilih media elektonik seperti internet dalam mencari tugas maupun bahan-bahan perkuliahan. Pemelihan media internet oleh para mahasiswa diantaranya disebabkan oleh, internet lebih banyak memuat informasi-informasi yang dicari, lebih ekonomis apabila mereka harus membeli sebuah buku sumber, bisa didapatkan kapan dan dimana saja. Perbincangan responden terhadap tema ini sebagaimana dinyatakan oleh (M3, M10) seperti tergambar dari beberapa hasil petikanpetikan wawancara berikut:

M.3 : ,...perilaku plagiat saat ini juga didukung oleh kemajuan teknologi, salah satunya jaringan internet yang mendunia, memudahkan, cepat, praktis dan murah..,

M.10 : ,...Jangankan internet, photo copy saja bisa dimainkan untuk membuat yang dikehendaki.

Tema kedua yaitu (beban tugas perkuliahan) berdasarkan hasil wawancara dengan beberapa responden, faktor yang kedua timbulnya perilaku plagiarisme adalah beban perkuliahan yang terlalu banyak. Perkara ini sangat dapat dimaklumi, seperti diketahui bahwa pada kebiasaannya dosendosen di perguruan tinggi di negeri maupun swasta di Indonesia biasanya pada setiap mata kuliah masing-masing dosen akan memberikan satu sampai tiga tugas yang harus disiapkan oleh seoarang mahasiswa, apabila coba kita kalkulasikan, ternyata seorang mahasiswa di Indonesia mesti menyiapkan kurang lebih 30 makalah sampai akhir semester. Perbincangan responden terhadap tema ini sebagaimana dinyatakan oleh (M6, M7, M10) seperti tergambar dari beberapa hasil petikan-petikan wawancara berikut:

M.6 : Semua dosen memberikan tugas, ada dalam bentuk artikel, resume, makalah, peta konsep, jadi banyak sekali tugas yang mesti diselesaikan dalam satu semester. 
M.7 : Mencari melalui internet lebih mudah dan cepat, kalau melalui buku butuh waktu yang lama, apa lagi buku di perpustakaan sangat kurang.

M.10 : Setiap dosen memberikan tugas sampai tiga buah, jadi sebagian mahasiwa mencari jalan pintas, karena harus bekejar dengan waktu yang tersedia.

Dari hasil wawancara mendalam yang telah peneliti lakukan sebagaimana tergambar pada petikan-petikan di atas dapat disimpulkan bahwa terdapat dua faktor penyebab timbulnya perilaku plagiarisme dikalangan mahasiswa dalam menyelesaikan tugas-tugas perkuliahan. Kedua faktor tersebut adalah (i) perkembangan teknologi informasi baik berupa elektronik, cetak, telah memudahkan mahasiswa dalam mengakses informasi yang diinginkan tidak terkecuali kemudahan dalam menyelesaikan tugas-tugas perkuliahan. (ii) terlalu tingginya volume atau beban tugas perkuliahan yang diberikan oleh setiap dosen dalam perkuliahan sehingga mahasiswa mengambil jalan pintas dengan budaya instan (cepat saji) dalam menyelesaikan tugas-tugas yang dibebankan tersebut. Kondisi di atas juga diperparah dengan terbatasnya waktu yang tersedia bagi mahasiswa untuk menyelesaikan semua tugas-tugas tersebut, dengan kata lain kurang seimbangnya antara waktu yang diberikan dengan tugas yang disediakan.

\section{PEMBAHASAN}

Pembahasan pada bagian akhir tulisan ini akan membicarakan seputar hasil penelitian yang telah ditemukan. Untuk lebih menarik, kedu-dua hasil penelitian ini akan dibahas berdasarkan teori-teori pendidikan, psikologi dan diperkuat oleh hasil-hasil penelitian yang telah dilakukan oleh peneliti terdahulu tentang permasalahan plagiarisme di kalangan mahasiswa.

1. Bentuk-bentuk perilaku plagiarisme

Temuan kajian ini secara jelas terdapat bahwa perilaku plagiarisme memang telah terjadi di kalangan mahasiswa fakultas Tarbiyah IAIN Imam Bonjol Padang dalam menyelesaikan tugas-tugas perkuliahan. Perilaku tersebut secara jelas dapat tergambar melalui tiga bentuk pencurian karya intelektual atau tulisan orang lain seperti mengambil ide orang lain yang kemudian diakui sebagai karya atau tulisan sendiri, mengambil ide atau batang tubuh pemikiran orang lain kemudian memfrasakan tulisan tersebut dengan kalimat sendiri, walaupun ide atau batang tubuh tulisan tidak berubah dan mengambil teks atau tulisan secara keseluruhan tanpa diberikan tambahan apapun.

Perilaku mencuri karya atau tulisan orang lain seperti yang dilakukan oleh mahasiswa berdasarkan hasil dapatan kajian ini merupakan salah satu bentuk perilaku menyimpang dalam teori ilmu kejiwaan dan bahkan perilaku seperti ini juga dianggap tidak bermoral (Goldgar 2001). Sebagian ahli ilmu kejiwaan menyebut para pelaku plagiator sebagai manusia-manusia dengan kepribadian machiavelianism atau juga dikenal dengan istilah psychopath, karena keperibadian seperti ini sangat suka berbohong, tidak pernah merasa bersalah meskipun merugikan orang lain, impulsive dan tidak memiliki rasa empati (Brandt 2002; Smith 1999). Perilaku tersebut sesuai dengan apa yang dikatakan oleh Greenberg \& Baron (2000) sebagai 'a personality trait involving a willingness to maniputate others for ane's own purposes".

Mungkin sebagian kita akan berfikir bahwa apakah tidak terlalu dini label tersebut diberikan kepada para plagiator akademik?. Terlepas dari label atau panggilan yang diberikan kepada para pelaku tersebut, namun menurut peneliti yakin dan dapat disepati bahwa pelaku plagiarisme tetap tidak bisa ditolerir karena plagiator tidak hanya manusia pelanggar undang-undang namun juga telah merusak integritas dunia akademik (Smith 1999).

Perilaku plagiarisme dalam dunia akademik di Indonesia bukanlah fenomena yang baru. Dunia pendidikan tinggi Indonesia telah cukup lama dicemari oleh gurita praktik penjiplakan. Bahkan, dalam sejarah 
pendidikan tinggi di negeri ini, tercatat dua menteri kabinet di era yang berbeda pernah dilaporkan terindikasi melakukan penjiplakan karya orang lain. Namun, kasus itu pun seakan lenyap seiring dengan berjalannya waktu. Apabila dikaitkan dengan hasil kajian ini, walaupun bentuk-bentuk tindakan plagiarisme yang dilakukan mahasiswa tersebut masih sekedar untuk memenuhi keperluan-keperluan tugas perkuliahan, akan tetapi menurut peneliti perilaku ini merupakan diantara salah satu embrio plagiarisme dunia akademik. Bentuk-bentuk perilaku plagiarisme mahasiswa dalam menyelesaikan tugas perkuliahan dalam penelitian didukung oleh kajian (Sutton 1991; Ward 1998).

2. Faktor-faktor penyebab timbulnya perilaku plagiarisme

Temuan kajian ini secara jelas terdapat bahwa terdapat dua sebab sebagai pendorong timbulnya perilaku plagiarisme di kalangan mahasiswa fakultas Tarbiyah IAIN Imam Bonjol Padang dalam menyelesaikan tugastugas perkuliahan. Kedua-dua faktor tersebut adalah (perkembangan teknologi informasi dan tingginya volume tugas perkuliahan dari dosen dengan alokasi waktu terbatas).

Tidak dapat dibantah lagi bahwa, perkembangan teknologi informasi setidaknya telah membawa dampak yang cukup besar terhadap perubahan cara manusia dalam membuat, menyampaikan dan cara mendapatkan informasi itu sendiri. Kini, tidaklah terlalu sulit jika seseorang ingin mendapatkan informasi yang dikehendaki. Bagaimana tidak, seperti yang dinyatakan oleh salah seorang responden dalam wawancara bahwa semuanya hanya tinggal mengadu kepada "Mbah Google" saja. Maka tidaklah terlalu mengherankan apabila faktor perkembangan teknologi informasi merupakan salah satu penyebab timbulnya perilaku plagiarisme. Seorang mahasiswa bisa mencari apa yang dikehendaki hanya dengan memasukan beberapa kalimat ke dalam google dan dengan seketika semua informasi tersebut akan keluar dengan sendirinya dan boleh diambil dengan barbagai cara. Dengan bahasa yang lebih sederhana peneliti menyimpulkan bahwa sekarang semua informasi berada di ujung jari jemari manusia. Dan bahkan saat ini terdapat begitu banyak halaman website yang menawarkan layanan pembuatan makalah, skripsi, tesis dan karya ilmiah lainnya seperti researchpaper. com dan term papers-on-file com (Hricko 1998).

Dapatan kajian juga secara jelas mendapati bahwa, tingginya volume beban perkuliahan yang diberikan para dosen pada setiap mata kuliah juga merupakan salah satu faktor yang menyumbang timbulnya perilaku plagiarisme di kalangan mahasiswa. Dan menurut beberapa orang responden hal ini diperperah oleh kurangnya alokasi waktu yang tersedia untuk menyelesaikan semua beban kuliah tersebut. Disamping itu, kurangnya budaya membaca dan tingginya perilaku 'cut and paste' juga diantara faktorfaktor penyumbang terjadinya perilaku plagiarisme (Zack 1998). Hasil penelitian juga didukung oleh (Schneider 1999) yang menyatakan, kurangnya waktu yang tersedia bagi mahasiswa dalam menyelesaikan tugastugas perkuliahan telah menggiring mereka kepada budaya instan dan 'cut and paste'.

Jika diamati secara teliti kedua-dua faktor di atas, sesungguhnya peneliti sampai kepada kesimpulan awal secara umum penyebab terjadinya perilaku plagiarisme di kalangan mahasiswa yaitu tersedianya sarana informasi yang begitu mudah didapatkan oleh mahasiswa melalui berbagai media informasi. Ketersediaan informasi tersebut ditunggu atau bertemu dengan tuntutan keperluan akademik yang tinggi yang mesti diselesaikan oleh mahasiswa dengan durasi waktu yang kurang seimbang. Sehingga para mahasiswa dengan leluasa mencari informasi yang diinginkan agar dapat lepas dari semua tugastugas perkuliahan yang mendesak (Auer \& Kruper 2001; Laird 2001).

\section{SIMPULAN}

Penelitian ini telah berhasil mengungkap bentuk-bentuk perilaku dan faktor-faktor 
penyebab timbulnya plagiarisme di kalangan mahasiswa Fakultas Tarbiyah IAIN-IB Padang dalam menyelesaikan tugas-tugas perkuliahan yang diberikan dosen. Penelitian menyimpulkan bahwa terdapat tiga bentuk tindakan plagiarisme yang dilakukan oleh mahasiswa yaitu:

1. Mengambil ide orang lain kemudian para mahasiswa mengakui hal tersebut sebagai karya atau buah dari pemikiran mereka sendiri

2. Mengambil tulisan orang lain kemudian para mahasiswa memparafrasakan tulisan orang lain tersebut dengan kalimat sendiri, walaupun ide atau batang tubuh tulisan tidak berubah.

3. Mengambil teks secara keseluruhan, selanjutnya tulisan tersebut ditulis kembali tanpa ada tambahan apapun dari mahasiswa

Hasil penelitian ini juga menyimpulkan bahwa terdapat dua faktor penyebab timbulnya perilaku plagiarisme di klangan mahasiswa tersebut yaitu.

1. Perkembangan teknologi informasi seperti media elektronik sehingga telah memudahkan para mahasiswa mendapatkan bahan-bahan perkuliahan dari sumbersumber tersebut.

2. Tingginya beban tugas perkuliahan yang diberikan oleh dosen, budaya instan dan tidak cukupnya waktu yang tersedia telah telah menggiring mahasiswa agar berperilaku plagiarisme.

\section{DAFTAR RUJUKAN}

Auer, N. \& Krupar, E.M. 2001. Mouse click Plagiarism: The role of Technology in Plagiarism and the Librarian's role in Combating it. Library Trends, 49 (3).

Bungin, B. 2003. Analisis data penelitian Kualitatif: Pemahaman Filosofis dan Metodologis ke Arah Pengusaan Model Aplikasi. Jakarta: P.T. Raja Grafindo Persada.

Chua Yan Piaw. 2006. Asas Statistik Penyelidikan. Kuala Lumpur: Mc Graw Hill.
Creswell, J.W. 2005. Research Design: Qualitative and Quantitative Approach. Thousand Oaks, CA: Sage Publication. Denzin, NK \& Lincoln, YS. 1994. "Introduction: Entering the Field of Qualitative Research.". Thousand Oaks: Sage Publications.

Davis, S. F. 1993. Cheating in College is for a Career: Academic Dishonesty in the 1990s. Paper presented at Theannual Meeting of the Southeatern Psychological Association, Atlanta, GA. (ERIC Document Reproduction Service No. ED 358 382).

Doris, D. 1986. Plagiarism in High School. English Journal. 75(2): 81-4.

Fishbein, L. 1993. Curbing Cheating and Restoring Academic Integrity. The Chronicle of Higher Education, 40.

Flick, U. 1998. An Introduction to Qualitative research. London: Sage Publication.

Gehring, D., E. M. Nuss dan G. Pavela. 1986. Issues and Perspectives on Academic Integrity. Columbus, $\mathrm{OH}$ : NASPA.

Hawley, C. S. 1984. The Thieves of Academe: Plagiarism in the University System. Improving College and University Teaching. 32: 35-39.

Jendrek, M.P. 1992. Students' Reactions to Academic Dishonesty. Journal of College Student Development. 33: 26073.

Kramer, Melinda G., Gleen Leggett, dan C. David Mead. 1995. Handbook For Writers. New Jersey: Prentice Hall

Sugiyono. 2005. Memahami penelitian kualitatif. Bandung: CV Alfabeta.

Saunders, E. J. 1993. Confronting Academic Dishonesty. Journal of Social Work Education. 29(2): 224-31.

Schneider, A. 1999. Why professors don't do more to stop students who cheat: some who have tried say that administrator, fearful or lawsuits, don't back them up. Chronicle of Higher Education, 45 (30), 8-10.

Wiersma, W. 2000. Research method in education: An introduction. Needham Heights, NY: Allyn \& Bacon. 
Yin, R.K. 1994. Case study research: Design and methods. 2nd Edition. Thousand Oaks, CA: Sage Publications.

Laird, E. 2001. We all pay for internet plagiarism. Education Digest. 67(3).

Lincoln, Y. \& Guba, E. G., 1994. Competing Paradigms in Qualitative Research Handbook of Qualitative Research, Thousand Oaks: Sage Publication Inc.

Rachmad, Edy. 2010. Fenomena Plagiarisme di Kampus. Jurnal Waspada. Medan.

Law.com Dictionary. http://dictionary. law.com - 22/4/03.

Utorodewo, Felicia, dkk. 2007. "Bahasa Indonesia: Sebuah Pengantar Penulisan Ilmiah". Jakarta: Lembaga Penerbit FEUI.

Wray, Alison dan Alleen Bloomer. 2006. Projects in Linguistics: Practical Guide to Researching Langguage. Oxfore University Prees 